\title{
Study of Alumni Engagement and its Relationship to University Curriculum Reforming
}

\author{
Hanjar Ikrima Nanda ${ }^{1}$, Sheila Febriani Putri ${ }^{2}$, Dhika Maha Putri ${ }^{3}$, Ria Zulkha Ermayda ${ }^{4}$, \\ Mohd. Rizal Palil ${ }^{5}$ \\ $\left\{\right.$ hanjar.ikrima.fe@um.ac.id $\left.{ }^{1}\right\}$ \\ Universitas Negeri Malang, Indonesia ${ }^{1,2,3,4}$ \\ Universiti Kebangsaan Malaysia, Malaysia ${ }^{5}$
}

\begin{abstract}
The need for labor after Covid-19 pandemic continues to increase the need for professional human resources. Human resources are required to be skilled in adapting to the new normal conditions, including in terms of work. Working skill is not only determined by academic, but also affected by emotional intelligence, especially soft skills. One of the efforts to optimize the soft skills of prospective graduates is through the role of alumni. The engagement of alumni in the development of education is considered important to provide learning that is relevant to the current era. Alumni, as experienced parties in the world of work, certainly understand very well what skills a prospective employee need. Based on this matter, universities are required to produce graduates who are able to answer challenges in the world of work. Through data collected by interviews and discussion with alumni who had worked, this research described the most needed soft skills in the business industry include, (1) communication skill; (2) leadership; (3) personal skill; (4) creative skill; and (5) interpersonal skill. In addition, this study also found the need for training designs related to soft skills. Training would be given by alumni who had experience in working. The training materials were adjusted to the industry conditions, according to the advice of alumni. The training was held for several times with the senior student participants who were about to graduate. We believe that the design of this training by alumni will help universities in producing graduates who are able to adapt to the world of work in the new normal era.
\end{abstract}

Keywords: Alumni, Curriculum, Human Resources, Soft Skills, Training Design.

\section{Introduction}

Covid-19 pandemic is challenging everyone in the world of work to survive in driving the economic wheels. Uneven modernization of society is finally urged to keep up with the changing era, including in the world of education. Graduates are expected to survive in the modern era. This ability should be supported by educational institutions to equip graduates with adequate skills. Graduates should be encouraged to be able to develop creativity and bring out their uniqueness, so as not to be swept away by the automation era [1]. The role of educational institutions is important to help students constructing knowledge and be resilient in facing the future.

One way to present an appropriate education is by involving the alumni. Barron [2] reveals that alumni are the real measure of program success and they are tangible evidence of program 
integrity and competence developed in learning. Alumni become important agents that deserve attention, and can objectively convey relevant information related to their experiences in practicing learning outcomes from the previous institutions. Rafik and Priyono [3] also conclude in their research that the most important thing that affects the satisfaction and loyalty of alumni is the institution capability to develop career skills by enriching the knowledge. Previously, Guevera and Stewart [4] find that if the university presidents want their alumni to be satisfied, it is necessary to ensure that their school curriculum includes practical material that is truly relevant to the careers. The results of education are important to support the ability of alumni in developing their careers.

The engagement of alumni in the development of education is considered important to provide learning that is relevant to the current era. Its development may include inspirators and role models, career mentors, while providing expertise and opportunities to access career development, increasing student recruitments, increasing efforts to raise funds and supporting the institution's reputation [5]. In the United States, a nonprofit private academic institution (NPAI) is able to utilize the alumni relations, so the students get the opportunity to learn from the alumni fund investment [6]. Alumni have a very important role in preparing human resources, in this case, are prospective university graduates. They have emotional bonds and interests in developing the alma mater. The role of alumni in universities can be in the form of support for alumni association networks, advocacy for universities, being placed on boards, work experience, volunteering, supervision, and mentoring to prospective scholars [7][8]. Through the relationship between the university and the alumni, it is expected that it can support the university in preparing graduates or human resources who are ready to enter the world of work. Therefore, maintaining positive alumni relations is very important for the university.

So far, the participation of alumni in advancing the education in institution is still lacking. An interview with one of the college alumni shows that alumni do not have a good place yet to transfer the knowledge with their juniors. Barron [2] also says that the alumni will often sleep away after graduation if there is no way to connect them with universities. The alumni say that they want to share their experiences at work, so that their juniors are educated about the world of work, which is often different from theory. On average, the alumni feel that their studies are still lacking, especially related to the practice in the world of work. The knowledge gained in college is still inadequate to make them ready in facing the work demands. Many graduates are not ready to work because they lack in adequate soft skills [9][10]. Wesley et al. [11] state, "Knowledge is still a necessary component to be provided to students but an adequate soft skills is critical in preparing students for a work in a real world.".

Working skill is not only determined by academic, but also emotional intelligence such as soft skills. The definition of soft skills can be seen as the level of commitment of a person that differentiates it from individuals, through skills and experience. Soft skills are related to communication and interpersonal skills [12]. Broadly speaking, soft skills are categorized into 3, namely: (1) interpersonal skills, such as teamwork and customer service skills; (2) thinking skills, such as making decisions and knowing how to learn; and (3) personal skills, such as social skills and self-management [12]. In the world of work, soft skills are as important as cognitive skills and are universal combination of interpersonal skills [13].

The soft skills required by companies include communication skills, professionalism, teamwork, leadership, interpersonal skills, customer service, and problem-solving [11]. Generally, individuals who have high rankings in soft skills are often the most wanted people by companies or employers [13]. Some of the most common indicators of soft skills required in the world of work include integrity, communication, politeness, responsibility, social skills, 
positive attitude, professionalism, flexibility, teamwork, and work ethic [14][13][11]. In addition, the human resources are also required to have self-management, communication, interpersonal skills, teamwork skills, the ability to work under pressure, imagination/creativity, critical thinking, willingness to learn, attention to detail, taking responsibility, planning, and organizing skills, insight, maturity, professionalism, and emotional intelligence [15].

This research examines the need for curriculum improvement by involving alumni as the output of Higher Education. The alumni experience in the world of work is helpful to develop the curriculum that is in accordance with the modern era. Their experiences and expectations regarding their learning institutions will be accommodated in this research, and are expected to produce graduates who are suited to the needs of the world of work.

\section{Research Method}

This is a qualitative research using case study method. This study examines the nature of engagement and its relationship with the development of college curriculum. The types of data in this study are divided into two, namely primary and secondary data. The primary data is the result of interviews and FGDs (online and offline) with the alumni of Accounting Department, Faculty of Economics, State University of Malang who had worked in several agencies. The secondary data consists of the study of literature, research, and other sources related to this research. Several alumni as the informants were selected by purposive sampling from each study program, that were Diploma 3 in Accounting study program, Bachelor of Accounting and Bachelor of Accounting Education. The selected informants in each study program were 10 alumni who worked in various institutions. The inclusion criteria were alumni who worked according to their study programs when they were still learning at the university. This selection was conducted with the expectation that the information could be linear with the research objectives and needs. Data analysis in this study was using an interactive model proposed by Miles and Huberman [16]. The components of the interactive model were; (1) data collection; (2) data reduction; (3) data presentation; and (4) drawing conclusion.

This research was conducted through interviews and FGDs with alumni, in order to be able to answer the research objectives in depth by gathering information related to what abilities and skills that must be owned by the university graduates in facing the needs of the world of work. In addition, the results of the interview could be used as a reference in determining education and teaching policies in the university. This is in line with Wesley [11] who said that curriculum adjustments in any field of study required interactive communication between students, faculties, and industry leaders. Such collaborative communication would describe the skills needed by students to adjust the work offered by employers/industries.

\section{Result and Discussion}

\subsection{Result}

Alumni play an important role in reforming the higher education curriculum as university agents spread across the business world. Alumni become a product description of a factory that reflects the quality of a university. Samina et al. [17] stated that alumni performance has a 
very important role in supporting the progress of the study program. Alumni participation is also significantly needed as an effort to improve the quality of the department. Progress for higher education cannot be separated from the evaluation of alumni regarding the improvement of the teaching and learning process, curriculum, course content, and the quality of lecturers. FGD with alumni is an implementation of alumni engagement through research activities. The realization of alumni engagement is expected to be able to generate input for continuous improvement in higher education. This continuous improvement will be a positive point in itself, given the rapid modernization of time. Graduates should be equipped with the ability to adapt to minimize skill imbalances while studying in campus and also when showing off performance in the world of work.

Based on this matter, this study attempts to examine alumni suggestions related to the curriculum through focus group discussions. FGD was held by inviting the alumni from three study programs majoring in accounting, and each study program was represented by 10 people. The results of the FGD found that students really needed soft skills when they worked. This is because the world of work is unpredictable, so one must quickly adapt to overcome various conditions. Soft skills are the combination of various skills i.e. communicational, personal, creative, leadership, interpersonal, and different personality traits that can make people navigate themselves and work well with others. Soft skills mean skills that show the ability to do work effectively and living with mature behavior [18].

"When working, we must be able to keep thinking clearly even when under pressure" (FP)

"The ability to work as a team is very important because not all tasks can be done alone" (DN)

The input from the alumni above is also supported by the results of observation on the results of the internship activities of accounting students. The internship evaluation sheet from the company states that the apprentice students have sufficiently mastered theory but lack in soft skills mastery. On the other hand, the industrial revolution has further increased the need for human resources capable of adapting to all conditions. The situation changes rapidly due to technology advancement. The industrial revolution requires quality human resources that are qualified, agile, adaptive, and responsive to rapid changes [19]. Working skill for a person is not only determined by academic aspects, but also by soft skills.

Based on the discussion results presented by the alumni, the soft skills most needed in the work industry include (1) communication skill, is the ability to express feelings and opinions in an appropriate manner. In addition, this ability also means listening to and responding to others' opinions with appropriate gesture and language; (2) leadership, is the capacity to make decisions when needed and how one organizes the resources under his authority; (3) personal skill, is the ability to analyze conditions and problems. This ability also means a person who is able to pay attention to moral values on the problems at hand; (4) creativity, is the ability where a person can do things in a different and innovative way with careful planning; and (5) interpersonal skill, that is when a person can maintain sympathy, empathy, and affection for the surrounding environment and accept other people as they are.

"The first impression when doing the test must be neat to show work readiness.

Sometimes, appearance will influence judgment." (C)

"When working, we must be willing to listen to others' opinions so that teamwork is maintained and the work can be completed on time" (YP)

"If there is a problem in the office, we must think creatively and innovatively in order to solve the problem immediately" $(P)$ 


\subsection{Discussion}

The university produces resources (alumni) who will be involved in the world of work. Therefore, to produce quality alumni, universities are required to be able to develop student potentials to be more innovative, creative, and professional. Zafarina [20] states that along with the time progress and technology advancement, the world of work and industry requires quality human resources in their respective fields. This is one of the indicators that must be fulfilled by universities in order to produce alumni as professional workers according to their expertise. The competence of graduates can be seen in several aspects. Competence in the workplace context is a combination of cognitive skills (technical knowledge, skills \& abilities), and personal characteristics or behavior (principles, attitudes, values , and motives), which comprise as individual's personality. These graduate competencies will help in adapting to the new society.

Alumni are the products of an educational institution. The quality of alumni shows the quality of the educational institution. To determine the quality of the graduates produced, it is not enough by looking at the output alone, for example from the ability to master knowledge, skills, and formal attitudes embodied in the Achievement Index (IP) but can also be detected from the output by measuring how many graduates can be employed in the world of work [20]. The employment of alumni is influenced by several factors, both internal and external factors. Internal factors are factors that exist within the alumni. One of the important internal factors in alumni is soft skill. Furthermore, Samina et al. [17] states that the inadequate soft skills of graduates and the increased level of competition between job seekers who have the same expertise/field of knowledge are two main factors for the length of time graduates (alumni) look for a job.

The results of discussion with alumni related to the development of soft skills in students are very important for the accounting department to implement. It is intended that accounting graduates are ready to face the world of work. The five skills needed are communication, leadership, creative, personal, and also interpersonal skills. Wesley [11] explains that communication skills are the most important, expressed by the three groups of industry, faculty, and students. These skills are the basics that must be possessed since the first time entering the world of work. Verbal and non-verbal communication convey the aims and objectives so that organizational goals are more easily achieved. As a superior, it is appropriate to be able to invite employees to communicate. Mintzberg [21] states that there is a skill for conveying information and also a skill for bridging individuals that a leader must master. This communication skill is actually needed by all parties, including among employees and between employees and the leaders. Communication in inseparable in human life.

Another skill that is needed in the world of work is leadership, both leading oneself and leading others. The attitude as a leader will make the person think critically, be able to overcome conflicts, respect others, and so on. This attitude is usually needed when working in a team. However, teamwork requires skill to position himself, when becoming a leader and when following the leader's direction. As an individual, the attitude to think strategically is also needed to quickly achieve the goals. Wesley [11] found that strategic thinking is the most important soft skill characteristic for an individual, in which this skill is in the soul of a leader.

Creative thinking is important in the world of work. The era of globalization that is moving rapidly, especially entering the era of the 5.0 industrial revolution, demands each individual to be adaptive. Acting creatively can accelerate the achievement of goals, so this skill is needed by each individual in it. Creativity can be used in producing solutions that are beneficial to the 
organization so that the decisions taken will be correct and effective. Creative people always think out of the box and have an open mind to approach something new [22]. These skills should be trained through quality education, as an effort to encourage the ability to think creatively as a requirement to face the demands, changes, and developments of time [23]. Universities can be used as a place to teach creativity to prospective graduates so that in the future they are ready to face the changing time.

Appearing as a capable individual is another important thing that one needs to have in the world of work. The ability to position oneself will make it easier to work together with various individual characteristics. These personal and interpersonal skills will bring out the identity of an individual to be side by side in the world of work. Managing emotions, generating sympathy, empathy will help conveying messages better. Sulianta [24] explains that this intrapersonal or personal skill will enable a person to organize himself in optimal work development, with time management, changes, and creative thinking. Therefore, personal and interpersonal skills will support the achievement of organizational goals. Not only leaders, the employees should also master this skill.

The provision of the five soft skills for students can be carried out through training that will be mentored by alumni. The training schedule will becarried out three times in one semester at the senior year. The students will get a certificate from this training activity. This activity will be initiated by giving a pretest before the training and it will end with a posttest to the students taking part in the training. Before completing this training activity, the students are required to give feedback on training activities. The feedback will be analyzed by the development team to evaluate this training activity so that any shortcomings of this activity can be followed up by the team. The soft skills material that will be given includes five main types of soft skills needed by students, including (1) communication; (2) leadership; (3) personal; (4) creative, and (5) interpersonal skills. The students can obtain these soft skills through participating in the training. Speakers in soft skills training are the alumni who have worked with the aim of bringing students closer to the facts and reality in the world of work. Soft skills training is expected to prepare the students to face the world of work not only with academic intelligence, but also with emotional intelligence. The assessment of this activity consists of 1) improvement on the pretest and posttest scores, 2) peer assessments, 3) selfreport assessments, and 4) assessment of the presenters.

\section{Conclusion}

The research related to the analysis of needs of world of work through FGD with alumni concludes that there are five main types of soft skills required by the students, which are (1) communication; (2) leadership; (3) personal; (4) creative, and (5) interpersonal skills. These soft skills can be obtained by the students through debriefing of the world of work in the form of training. The training schedule is held three times in one semester at the senior year. The speakers in soft skill training are alumni who have worked with the aim of bringing the students closer to the facts and reality in the world of work. Soft skill training is expected to prepare students to face the world of work not only with academic intelligence, but also with emotional intelligence. 


\section{References}

[1] D. Ariely, "People Don’t Bulit Lasting Relationships with Algorithms," 2017. [Online]. Available:

https://www.google.com/search?q=translate\&rlz=1C1CHBF_enID865ID865\&oq=trans\&aqs=c hrome.0.69i59j69i57j016.1648j0j4\&sourceid=chrome\&ie=UTF-8. [Accessed: 01-Jun-2020].

[2] J. Barron, "Building a chain of success in marketing higher education: the alumni connection," Ind. Commer. Train., 2015.

[3] A. Rafik and A. Priyono, "A new insight into alumni satisfaction model for Islamic higher education institutions (IHEI)," Manag. Res. Rev., 2018.

[4] S. Guevera, C. \& Stewart, "Do Student Evaluations Match Alumni Expectation?," Manag. Financ., vol. 37, no. 7, pp. 610-623, 2011.

[5] Noraisyah; Asmah, "Role Of Alumni In University Development," 2015. [Online]. Available: http://uniselalumni.wixsite.com/uniselalumniconnect/single-post/2015/10/15/ROLE-OF-

ALUMNI-INUNIVERSITY-DEVELOPMENT. [Accessed: 15-Mar-2020].

[6] S. Reid, J. Muenzen, and R. Rezvanian, "Value Add: A Finance Case Study on How to Enhance Student Learning Experience through Student Managed Investment Fund and Engaged Alumni Network.," J. Int. Educ. Bus., vol. 13, no. 1, pp. 131-143, 2020.

[7] A. Chang, N. T. Churyk, and S. Yu, "Reducing the Observed Curriculum Perception Gaps between Stakeholders.," Res. High. Educ. J., vol. 29, 2015.

[8] B. N. Frisby, R. J. Sidelinger, and N. T. Tatum, "Alumni recollections of interactions with instructors and current organizational identification, commitment, and support of the university," Commun. Reports, vol. 32, no. 3, pp. 161-172, 2019.

[9] P. Verma, A. Nankervis, S. Priyono, N. M. Salleh, J. Connell, and J. Burgess, "Graduate workreadiness challenges in the Asia-Pacific region and the role of HRM," Equal. Divers. Incl. An Int. J., 2018.

[10] J. Chan, "Is China creating a workforce with no soft skills?," 2015. [Online]. Available: https://www.britishcouncil.org/voices-magazine/china-creating-workforce-no-soft-

skills\#: :text=A new British Council report,of China's biggest challenges yet.\&text=This means that China's increase,such as Netherlands or Turkey. [Accessed: 30-Jun-2020].

[11] S. C. Wesley, V. P. Jackson, and M. Lee, "The perceived importance of core soft skills between retailing and tourism management students, faculty and businesses," Empl. Relations, 2017.

[12] M. L. Matteson, L. Anderson, and C. Boyden, “'Soft Skills': A Phrase in Search of Meaning," portal Libr. Acad., vol. 16, no. 1, pp. 71-88, 2016.

[13] M. M. Robles, "Executive perceptions of the top 10 soft skills needed in today's workplace," Bus. Commun. Q., vol. 75, no. 4, pp. 453-465, 2012.

[14] M. V Gruzdev, I. V Kuznetsova, I. Y. Tarkhanova, and E. I. Kazakova, "University Graduates' Soft Skills: The Employers' Opinion.," Eur. J. Contemp. Educ., vol. 7, no. 4, pp. 690-698, 2018.

[15] W. Teng, C. Ma, S. Pahlevansharif, and J. J. Turner, "Graduate readiness for the employment market of the 4th industrial revolution," Educ. Train., 2019.

[16] M. B. Miles and A. M. Huberman, “Analisis Data Kualitatif.” Jakarta: UI press, 1992.

[17] S. Riaz, R. Ahmed, R. Parkash, and M. J. Ahmad, "Determinants of Stock Market Investors' Behavior in COVID-19: A Study on the Pakistan Stock Exchange," 2020.

[18] M. S. Kumar and M. T. Agarwal, "Assessment Of Soft Skills Among Senior Secondary Students In Moradabad District Of Uttar Pradesh, India."

[19] A. Sopa, M. Asbari, A. Purwanto, P. B. Santoso, D. H. Mustofa, S. Maesaroh, M. Ramdan, and R. Primahendra, "Hard Skills versus Soft Skills: Which are More Important for Indonesian Employees Innovation Capability," Int. J. Control Autom., vol. 13, no. 2, pp. 156-175, 2020.

[20] N. Zafarina, "Studi Kepuasan Pengguna Lulusan Program Studi Pendidikan Teknik Bangunan Universitas Negeri Jakarta di Bidang Kependidikan,” J. Pendidik. Tek. Sipil, vol. 9, no. 2, pp. 81-91, 2019.

[21] H. Mintzberg, "The structuring of organizations: A synthesis of the research. 1979," Englewoods Cliffs: Prentice-Hall, 2016. 
[22] S. Panggabean, "Hubungan Berpikir Kreatif Dan Softskill Terhadap Prestasi Belajar Kewirausahaan Prodi Pendidikan Matematika Fkip Umsu," Numer. J., vol. 6, no. 1, pp. 64-75, 2019.

[23] T. Y. E. Siswono, A. H. R. Abadi, and H. Abdul, "Pengembangan Model Pembelajaran Matematika Berbasis Pengajuan dan Pemecahan Masalah Untuk Meningkatkan Kemampuan Berpikir Kreatif Siswa," Dep. Pendidik. Nasional, Jakarta, 2009.

[24] F. Sulianta, "Panduan Lengkap Pengembangan Softskill Interpersonal dan Intrapersonal Skill," Yogyakarta Andi Offset, 2018. 